\title{
Altered cytokine profiles in laminopathic patients
}

\author{
Pia Bernasconi \\ From 1st French-Italian meeting on laminopathies and other nuclear envelope-related diseases \\ Marseille, France. 15-16 January 2015
}

Prelamin A accumulation is known to dysregulate the NF- $\kappa \mathrm{B}$ signaling cascade, causing a secretion of high levels of proinflammatory cytokines, which in turn might contribute to the pathologic aging observed in laminopathies, and in particular in HGPS [1]. In collaboration with researchers and clinicians of the Italian network for Laminopathies, we wondered whether it was possible to identify a pattern of cytokine expression that could discriminate laminopathy from other forms of muscular dystrophy and/or cardiomyopathy and a laminopathy with a cardiac involvement from one with only muscle involvement, with the final goal to identify biomarker(s) helpful for diagnosis, prognosis and evaluation of therapy efficacy. We analysed the cytokine profiles of sera collected from 37 patients affected by different forms of laminopathy (all $L M N A$ mutations), 9 patients affected by genetically defined non-LMNA muscular dystrophy and 27 healthy individuals. Sera were screened for the expression levels of 16 cytokines, 6 chemokines, 5 growth factors and TGF-beta1, 2 and 3 by Luminex technology. Some pro-inflammatory cytokines were found to be differentially expressed in cardiopathic and non-cardiopathic patients compared to healthy controls, and among laminopathies with muscle and cardiac involvement, laminopathies without myopathy and muscular dystrophies. Interestingly, TGF-beta2 serum levels were higher in the $L M N A$ patients than in healthy individuals and in patients with non-LMNA muscular dystrophy, suggesting a direct link between LMNA mutations and dysregulation of TGFbeta2 pathway, as indicated by previous and recent experimental studies $[2,3]$.

Published: 11 November 2015

Correspondence: pbernasconi@istituto-besta.it

Neurology IV Unit - Neuroimmunology and Neuromuscular Diseases Unit, Foundation IRCCS Neurological Institute "Carlo Besta", Milan, Italy
References

1. Osorio FG, Barcena C, Soria-Valles C, Ramsay AJ, de Carlos F, Cobo J, et al: Nuclear lamina defects cause ATM-dependent NF-kappaB activation and link accelerated aging to a systemic inflammatory response. Genes \& development 2012, 26(20):2311-24.

2. Avnet S, Pallotta R, Perut F, Baldini N, Pittis MG, Saponari A, et al: Osteoblasts from a mandibuloacral dysplasia patient induce human blood precursors to differentiate into active osteoclasts. Biochimica et biophysica acta 2011, 1812(7):711-8.

3. Evangelisti C, Bernasconi P, Cavalcante P, Cappelletti C, D'Apice MR, Sbraccia P, et al: Modulation of TGFbeta 2 levels by lamin A in U2-OS osteoblast-like cells: understanding the osteolytic process triggered by altered lamins. Oncotarget 2015, 6(10):7424-37.

doi:10.1186/1750-1172-10-S2-014

Cite this article as: Bernasconi: Altered cytokine profiles in laminopathic patients. Orphanet Journal of Rare Diseases 2015 10(Suppl 2):O14.
Submit your next manuscript to BioMed Central and take full advantage of:

- Convenient online submission

- Thorough peer review

- No space constraints or color figure charges

- Immediate publication on acceptance

- Inclusion in PubMed, CAS, Scopus and Google Scholar

- Research which is freely available for redistribution
() Biomed Central
() Biomed Central

(c) 2015 Bernasconi This is an Open Access article distributed under the terms of the Creative Commons Attribution License (http:// creativecommons.org/licenses/by/4.0), which permits unrestricted use, distribution, and reproduction in any medium, provided the original work is properly cited. The Creative Commons Public Domain Dedication waiver (http://creativecommons.org/publicdomain/ zero/1.0/) applies to the data made available in this article, unless otherwise stated. 